\title{
Analysis of abrB Expression during the Infectious Cycle of Bacillus thuringiensis Reveals Population Heterogeneity
}

\author{
Samia Ben Rejeb, Didier Lereclus and Leyla Slamti* \\ Micalis Institute, Institut National de la Recherche Agronomique, AgroParisTech, Université Paris-Saclay, Jouy-en-Josas, \\ France
}

Using the model host/pathogen pair Galleria mellonella/Bacillus thuringiensis, we have shown that these bacteria could kill their insect host, survive in its cadaver and form spores by sequentially activating virulence, necrotrophism and sporulation genes. However, the population isolated from the cadavers was heterogeneous, including non-sporulating cells in an unknown physiological state. To characterize these bacteria, we used a transcriptional fusion between the promoter of a gene expressed during early

OPEN ACCESS

Edited by: Weiwen Zhang,

Tianjin University, China

Reviewed by:

Mario Soberón

Universidad Nacional Autónoma de México, Mexico

Akos T. Kovacs,

Technical University of Denmark,

Denmark

${ }^{*}$ Correspondence:

Leyla Slamti

leyla.slamti@inra.fr

Specialty section:

This article was submitted to

Systems Microbiology,

a section of the journal

Frontiers in Microbiology

Received: 31 August 2017 Accepted: 28 November 2017 Published: 12 December 2017

Citation:

Ben Rejeb S, Lereclus D and Slamti L (2017) Analysis of abrB Expression during the Infectious Cycle of Bacillus thuringiensis Reveals

Population Heterogeneity.

Front. Microbiol. 8:2471.

doi: 10.3389/fmicb.2017.02471 exponential growth $(a b r B)$ and a reporter gene encoding a destabilized version of GFP, in combination with a fluorescent reporter of the necrotrophic state. The composition of the bacterial population during infection was then analyzed by flow cytometry. We showed that the PabrB promoter was activated in the population that had turned on the necrotrophic reporter, suggesting a re-entry into vegetative growth. Strikingly, the cells that did not go through the necrotrophic state did not activate the PabrB promoter and appear as a dormant subpopulation. We propose a new model describing the $B$. thuringiensis cell types during infection.

Keywords: population heterogeneity, single cell analysis, Bacillus thuringiensis, infectious cycle, dormancy

\section{INTRODUCTION}

Bacteria are often exposed to changes in their environment. Pathogenic bacteria in particular have to face an array of environments that change with the progression of the disease. They adapt most of the time by modifying their gene expression profile in response to the signals they receive. And interestingly, a clonal population will not always behave as a whole. Genetically identical bacteria can differentiate into specialized cell-types that will provide different answers to the signal received (Lopez and Kolter, 2010; Verplaetse et al., 2015; Mouammine et al., 2017).

Our model bacteria belong to the Bacillus cereus group. This group is composed of $8 \mathrm{Gram}-$ positive and sporulating species including $B$. anthracis, B. thuringiensis and B. cereus sensu stricto. These pathogens are responsible for infections in humans and in animals. B. anthracis is the agent of anthrax (Mock and Fouet, 2001). B. cereus mainly causes food-borne toxi-infections and is also an opportunistic pathogen responsible of endocarditis, meningitis and endophthalmitis (Stenfors Arnesen et al., 2008; Bottone, 2010). B. thuringiensis is an insect pathogen whose host specificity depends on the production of insecticidal toxins (Deng et al., 2014). The entomopathogenic properties of this bacterium are widely used in the world for pest control (Sanahuja et al., 2011; Sanchis, 2011). 
To understand the mechanisms involved in the pathogenicity of these bacteria we work with the insect model Galleria mellonella. This infection model has been successfully used to characterize numerous genes involved in the pathogenic properties of B. cereus and B. thuringiensis (Salamitou et al., 2000; Fedhila et al., 2006; Raymond et al., 2010). These bacteria are capable of carrying out a full infectious cycle in the larva of this insect. We have shown that this process is composed of three major phases (for a review Slamti et al., 2014). At the beginning of the infection, virulence factors are expressed under the control of the quorum sensor PlcR. These factors, which include proteases, phospholipases and cytotoxins, allow the bacteria to invade its host and to kill it (Salamitou et al., 2000). After the death of the insect, NprR, another quorum sensor, will trigger a necrotrophic lifestyle permitting the bacteria to survive in the cadaver (Dubois et al., 2016). Finally, the cells will sporulate and will be able to disseminate and withstand hostile environmental conditions.

A recent study reported the differentiation process of cells in insect cadavers, using fluorescent reporters under the control of promoters reflecting the activity of the regulators responsible for virulence, necrotrophism and sporulation at the cell level (Verplaetse et al., 2015). Although these physiological states take place in a sequential manner in a cell, the necrotrophic phase is only triggered in a part of the population in the insect cadaver, suggesting an activation specificity linked to the environment. It was also shown that sporulation only occurs in the subpopulation that has activated the necrotrophic regulon. This is in agreement with the fact that the apo form of NprR inhibits sporulation, whereas NprR in complex with its signaling peptide NprX, activates the necrotrophic genes (Perchat et al., 2016). We also identified a category of cells that did not express any of the previously described reporters in biofilm and in the host (Verplaetse et al., 2015, 2016). This category represented about $20 \%$ of the population throughout the infectious process.

Here we investigated the physiological state of the cells that did not enter the necrotrophic state, since the necrotrophic sub-population is the most inclusive. We sought to determine if these cells were actively growing bacteria. To monitor the vegetative state of these bacteria we chose to assay the activity of the promoter of the $a b r B$ gene during insect infection using a fluorescent reporter. This gene encodes the AbrB transition state regulator and is transcribed during the transition from lag to exponential phase and during early exponential phase (O'Reilly and Devine, 1997; Lucking et al., 2009). This central regulator has been shown to repress the expression of stationary phase genes in B. subtilis (Perego et al., 1988; Strauch and Hoch, 1993) as well as the synthesis of the cereulide toxin synthesis and the expression of the inhA1 metalloprotease-encoding gene in B. cereus (Grandvalet et al., 2001; Lucking et al., 2009). We engineered a $B$. thuringiensis-improved allele of the bright and fast folding sfGFP (Pedelacq et al., 2006) and, in order to follow fluctuations in gene expression, we destabilized the resulting protein by using the $s s r A$-mediated peptide tagging system that addresses specifically tagged proteins to the Clp degradation machinery in Escherichia coli and in B. subtilis (Keiler et al., 1996; Gottesman et al., 1998; Wiegert and Schumann, 2001). Using this tool, we showed that the $a b r B$ gene is expressed at the beginning of the infection and at a later stage of the process, only in cells that already went through the necrotrophic state. However, there is still a bacterial population in an unknown physiological state and we show that more than $60 \%$ of this population are living cells.

\section{MATERIALS AND METHODS}

\section{Bacterial Strains and Growth Conditions}

The acrystalliferous B. thuringiensis $407 \mathrm{Cry}^{-}$strain (Bt 407-) (Lereclus et al., 1989) was used as the parental strain to create all the strains used in this study. E. coli strain DH5 $\alpha$ (Taylor et al., 1993) was used as the host strain for plasmid construction. E. coli strain ET12567 (MacNeil et al., 1992) was used to prepare DNA prior to electroporation in B. thuringiensis. Cells were grown in LB medium ( $1 \%$ tryptone, $0.5 \%$ yeast extract, $1 \%$ $\mathrm{NaCl})$ or HCT medium $(0.7 \%$ casein hydrolysate, $0.5 \%$ tryptone, 0.68\% KH2PO4, 0.012\% MgSO 4 7H2O, 0.00022\% MnSO 4 4H2O, $0.0014 \% \mathrm{ZnSO} 47 \mathrm{H} 2 \mathrm{O}, 0.008 \%$ ferric ammonium citrate, $0.018 \%$ $\mathrm{CaCl} 24 \mathrm{H} 2 \mathrm{O}, 0.3 \%$ glucose, $\mathrm{pH} 7.2$ ) (Lereclus et al., 1982) at $37^{\circ} \mathrm{C}$ and stored at $-80^{\circ} \mathrm{C}$ in $\mathrm{LB}$ containing $15 \%$ glycerol.

For $B$. thuringiensis cultures, to corresponds to the beginning of the transition between the exponential and stationary phases of growth.

The antibiotic concentrations used for selection of B. thuringiensis and E. coli were as follows: erythromycin, $10 \mu \mathrm{g} / \mathrm{mL}$; ampicillin, $100 \mu \mathrm{g} / \mathrm{mL}$. Chloramphenicol was used at a concentration of $100 \mu \mathrm{g} / \mathrm{mL}$ to block the synthesis of proteins (Periago et al., 2002) in B. thuringiensis.

When required, xylose was used at a concentration of $20 \mathrm{mM}$.

\section{Plasmid and Strain Constructions}

DNA manipulations are detailed in the Supplementary Experimental Procedures. All the plasmids and strains used in this study are indicated in Tables 1, 2. Oligonucleotides are listed in Supplementary Table S1.

\section{In Vitro Growth of the Cells for Measurement of the GFP-Based Fluorescence}

To assay the GFP-based fluorescence of cells harboring the $s f g f p$ gene and its derivatives designed to improve fluorescence, overnight cultures incubated at $30^{\circ} \mathrm{C}$ in $\mathrm{HCT}$ medium supplemented with erythromycin were diluted 1000fold in $\mathrm{HCT}$ and incubated at $37^{\circ} \mathrm{C}$ under agitation until an $\mathrm{OD}_{600}$ of 0.5 . Xylose was then added and growth was resumed. Cells were harvested at the time of xylose addition (T0) as well as at other time points after xylose addition (Tn). Cultures were carried out in the same way to assay the GFP-based fluorescence of cells harboring the $g f p_{B t e}$ gene and its derivatives designed to destabilize the GFP, except that chloramphenicol was added to the cells $1 \mathrm{~h}$ after xylose addition.

In all cases, the cells were harvested and fixed as described in Verplaetse et al. (2015). Essentially, the cells were centrifuged, fixed for $7 \mathrm{~min}$ in PBS-formaldehyde $4 \%$ then washed in PBS. The 
pellet was then resuspended in GTE buffer (Vlamakis et al., 2008) and kept at $4^{\circ} \mathrm{C}$ until flow cytometry analysis or microscopy.

\section{In Vivo Experiments}

Intrahemocoelic injection experiments with G. mellonella were carried out essentially as described previously (Salamitou et al., 2000; Verplaetse et al., 2015). For each strain, 20 larvae were injected each with $2.10^{4}$ bacteria and kept at $30^{\circ} \mathrm{C}$ for $72 \mathrm{~h}$. $18 \mathrm{~h}$ after injection, surviving insects were eliminated. At each time point, B. thuringiensis cells were harvested from 2 or 3 dead insects as follows: the larva was cut open, transferred to a $1.5 \mathrm{~mL}$ Eppendorf tube containing $1 \mathrm{ml}$ of PBS and vortexed. The suspension was pipetted into a new $1.5 \mathrm{~mL}$ Eppendorf tube (leaving behind most of the large insect debris). The sample was centrifuged and the pellet was resuspended in PBS-formaldehyde $4 \%$, fixed for 7 min then washed in PBS. This suspension was filtered onto a cotton pad in a $1 \mathrm{~mL}$ syringe in order to retain the cadaver debris and recover the bacterial cells in the filtrate. These

TABLE 1 | Plasmids used in this study.

\begin{tabular}{|c|c|c|}
\hline Name & Relevant information & Reference \\
\hline pHT304 & Replicative multicopy E. coli/B. thuringiensis shuttle vector. & Arantes and Lereclus, 199 \\
\hline pHT304.18 & Replicative multicopy E. coli/B. thuringiensis shuttle vector. & Agaisse and Lereclus, 199 \\
\hline p304-Pxyl+ & $\begin{array}{l}\text { pHT304 harboring a modified version of the xylose-inducible promoter region of xylA to enhance } \\
\text { translation efficiency (Stammen et al., 2010). The original sequence AGGGGGAATCACATG was } \\
\text { changed to AGGAGGTGACACCATG were the RBS is in bold letters and the translation start site is } \\
\text { underlined. }\end{array}$ & Slamti et al., 2015 \\
\hline $\mathrm{pPX}^{\prime}{ }_{s f} g f p$ & $\begin{array}{l}\text { sf } g f p \text { was amplified by PCR from pCM11 (Pedelacq et al., 2006) using primer pair sfgfp1/sfgfp2, } \\
\text { digested with Bglll and Knpl, and cloned between the BamHI and Kpnl restriction sites of } \\
\text { pHT304.18-Px (Slamti and Lereclus, 2002). This created a transcriptional fusion between the } \\
\text { xylose-inducible promoter region of } x y I A \text { and }{ }_{s f} g f p .\end{array}$ & This study \\
\hline $\mathrm{pPx} x^{\prime} g p_{B t}$ & $\begin{array}{l}\text { B. thuringiensis codon optimized } g f p_{B t} \text {, synthesized and cloned in the pEX plasmid by Eurofins } \\
\text { Genomics (France), was amplified by PCR from this vector using primer pair sfgfp1/sfgfpBt2, digested } \\
\text { with Bglll and Knpl, and cloned between the BamHl and Kpnl restriction sites of pPx to create a } \\
\text { transcriptional fusion between PxylA and } g f p_{B t} \text {. }\end{array}$ & This study \\
\hline$p P x+' g f p_{B t}$ & $\begin{array}{l}\text { B. thuringiensis codon optimized } g f p_{B t} \text {, synthesized and cloned in the pEX plasmid by Eurofins } \\
\text { Genomics (France), was amplified by PCR from this vector using primer pair sfgfpBt1/sfgfpBt2, } \\
\text { digested with Bsal and Kpnl, and cloned between the Ncol and Kpnl restriction sites of p304-Pxyl+ to } \\
\text { create a transcriptional fusion between Pxyl+ and } g f p_{B t} \text {. }\end{array}$ & This study \\
\hline$p x^{\prime} g f p_{B t e}$ & 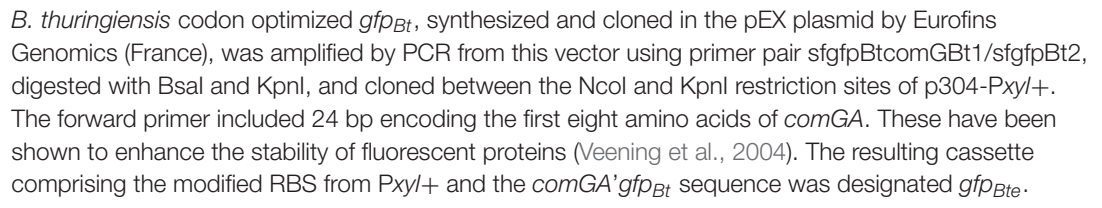 & This study \\
\hline $\begin{array}{l}\text { pPx'gfp }{ }_{B t e} \text { LAA } \\
\text { LVAIAAV/ASV }\end{array}$ & 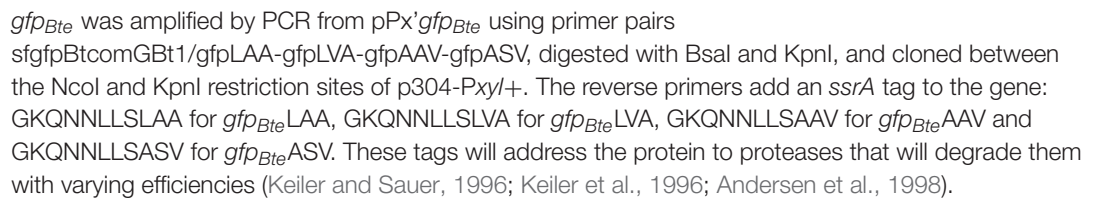 & This study \\
\hline pHT-gfp $p_{B t e} \mathrm{AAV}$ & $\begin{array}{l}g_{f p_{B t e}} \mathrm{AAV} \text { was amplified by PCR from pPx'gfp }{ }_{B t e} \mathrm{AAV} \text { using primer pair Xyl10/PU, and cloned between } \\
\text { the Smal and EcoRI restriction sites of } \mathrm{pHT} 304.18 .\end{array}$ & This study \\
\hline pPabrB'gfp ${ }_{B t e} A A V$ & $\begin{array}{l}\text { The promoter region of the abrB gene was amplified by PCR from the chromosome of Bt } 407 \text { using } \\
\text { primer pairs PabrB-F-Xbal/PabrB-R-Ascl and cloned between the Xbal and Ascl restriction sites of } \\
\text { pHT-gfp } \text { Bte }_{\text {AAV. }}\end{array}$ & This study \\
\hline pPnprA'mcherry $L G C$ & $\begin{array}{l}\text { pHT304.18 harboring a transcriptional fusion between the promoter of } n p r A \text { and the } \\
\text { B. thuringiensis-adapted mcherry reporter gene. }\end{array}$ & Verplaetse et al., 2015 \\
\hline $\begin{array}{l}\text { pPabrB'gfp }{ }_{B t e} \text { AAV- } \\
\text { PnprA'mcherry }\end{array}$ & 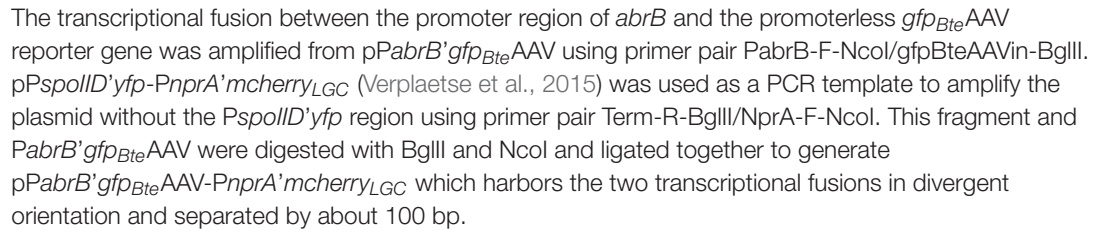 & This study \\
\hline pPaphA3'sf gfp & $\begin{array}{l}\text { sf gfp was amplified by PCR from pCM11 (Pedelacq et al., 2006) using primer pair sfgfp1/sfgfp2 and } \\
\text { digested with Bglll and EcoRI. PaphA3 was amplified from pDG792 (Guerout-Fleury et al., 1995) using } \\
\text { primer pair PkanHind1/PkanBam2 and digested with HindllI and BamHI. Both fragments were cloned } \\
\text { between the Hindlll and EcoRI restriction sites of pHT304.18 generating a transcriptional fusion } \\
\text { between the constitutive PaphA3 promoter and }{ }_{s f} \text { gfp. }\end{array}$ & This study \\
\hline
\end{tabular}


were then concentrated by centrifugation, resuspended in GTE buffer (Vlamakis et al., 2008) and kept at $4^{\circ} \mathrm{C}$ until flow cytometry analysis or microscopy.

For the assessment of the percentage of live cells in the bacterial population in insect cadavers, the experiments were carried out in the same manner except that the cells were not fixed with formaldehyde. After filtration on the cotton pad, the suspension was centrifuged, resuspended in saline, incubated with the SYTOX Green Dead Cell Stain (Molecular Probes) according to the manufacturer's instructions and analyzed immediately with the flow cytometer. Dead bacteria will present a bright green fluorescence compared to live cells.

\section{Flow Cytometry Analysis}

Fluorescence was measured on a CyFlow Space cytometer (Partec, France). Details about the parameters used to collect fluorescence and the softwares used to analyze the data are given in the Supplementary Experimental Procedures. The different populations were identified using histograms or bi-parametric cytograms. GFP- or mCherry-expressing cells were identified as cells giving a higher signal intensity than the reporterless cells used as controls.

\section{Fluorescence Microscopy}

Cells were observed with an AxioObserver.Z1 Zeiss inverted fluorescence microscope equipped with a Zeiss AxioCam MRm digital camera and with Zeiss fluorescence filters. GFP was imaged using the $38 \mathrm{HE}$ filter (excitation: BP 470/40, beam splitter: FT 495, emission: 525/50). mCherry was imaged using the 45 HE filter (excitation: BP 590/20, beam splitter: FT 605, emission: 620/14). Images were processed using the $\mathrm{ZEN}$ software package.

\section{Nucleotide Sequence Accession Numbers}

The DNA sequence of the plasmid containing the $g f p_{B t e} \mathrm{AAV}$ sequence was submitted to GenBank and is available under the accession number MF673728.

\section{RESULTS}

\section{Construction of a GFP Variant Highly Expressed in $B$. thuringiensis}

To facilitate the analysis of gene expression in B. thuringiensis, we engineered a highly expressed version of the sfGFP. We used the reporterless ${ }_{s f} g f p$ (Pedelacq et al., 2006) under the control of the xylose-inducible PxylA promoter as a template for our improvement procedure. $s f f p$ encodes a version of the Aequorea victoria GFP that has been shown to be four times brighter and that folds 4 times faster in vivo than GFPmut3 (Milde, 2008). We modified the ${ }_{s f} g f p$ gene and the features required for its translation to adapt it to $B$. thuringiensis. Our first step was to change the codon usage to one that would correspond better to that of our strain, using the GENEius software and the associated B. thuringiensis serovar thuringiensis codon usage table (Eurofins Genomics). We designated this allele $g f p_{B t}$. We then modified the RBS present in the promoter region of PxylA to the improved RBS+, that resulted in a twofold increase in protein production in B. megaterium, as described in Stammen et al. (2010). Finally, we added the first $24 \mathrm{bp}$ of comGA to the 5' end of the ${ }_{s f} g f p$ coding sequence. The corresponding eight amino acids have been shown to enhance the stability of fluorescent proteins (Veening et al., 2004). The resulting cassette comprising the modified RBS and the comGA' $g f p_{B t}$ sequence was designated $g f p_{B t e}$. Using

TABLE 2 | Strains used in this study.

\begin{tabular}{|c|c|c|}
\hline Name & Relevant information & Reference \\
\hline Bt (pHT304) & Bt $407^{-}$carrying the empty pHT304 vector and used as a Fluorescence ${ }^{-}$control. & This study \\
\hline $\mathrm{Bt}(\mathrm{pPx})$ & Bt $407^{-}$carrying the empty pPx vector and used as a Fluorescence ${ }^{-}$control. & This study \\
\hline $\mathrm{Bt}\left(\mathrm{pPx}{ }_{s f}^{\prime} g f p\right)$ & $\begin{array}{l}\text { Bt } 407^{-} \text {used to measure the fluorescence generated by the transcriptional fusion between the } \\
\text { xylose-inducible promoter of } x y / A \text { and }{ }_{s f} g f p .\end{array}$ & This study \\
\hline Bt (pPx'gfp $\left.p_{B t}\right)$ & $\begin{array}{l}\text { Bt } 407^{-} \text {used to measure the fluorescence generated by the transcriptional fusion between the } \\
\text { xylose-inducible promoter of } x y / A \text { and the } B \text {. thuringiensis codon-optimized } g \mathrm{fp}_{B t} \text {. }\end{array}$ & This study \\
\hline$B t\left(p P x+' g f p_{B t}\right)$ & $\begin{array}{l}\text { Bt } 407^{-} \text {used to measure the fluorescence generated by the transcriptional fusion between Pxyl+ and } \\
\text { the } B \text {. thuringiensis codon-optimized } g f p_{B t} \text {. }\end{array}$ & This study \\
\hline Bt (pPx'gfp $\left.p_{B t e}\right)$ & $\begin{array}{l}\text { Bt } 407^{-} \text {used to measure the fluorescence generated by the transcriptional fusion between Pxyl+ and } \\
\text { the } B \text {. thuringiensis codon-optimized } g f p_{B t} \text { to which the sequence encoding the first eight amino acids } \\
\text { of comGA have been added. }\end{array}$ & This study \\
\hline $\begin{array}{l}\text { Bt (pPx'gfp } p_{B t e} L_{A A} \\
\text { LVA/AAV/ASV) }\end{array}$ & $\begin{array}{l}\text { Bt } 407^{-} \text {used to measure the fluorescence generated by the transcriptional fusion between Pxyl+ and } \\
\text { gfp }_{\text {Bte }} \text { to which a degradation tag has been added. }\end{array}$ & This study \\
\hline Bt (pPabrB'gfp Bte $_{\text {AAV) }}$ & $\begin{array}{l}\text { Bt } 407^{-} \text {in which we measure the activity of the promoter of abrB using a reporter gene encoding an } \\
\text { unstable GFP. }\end{array}$ & This study \\
\hline $\begin{array}{l}\text { Bt } \\
\left.\text { (pPnprA'mcherry }{ }_{L G C}\right)\end{array}$ & Bt $407^{-}$in which we measure the activity of the promoter of nprA using the mcherry reporter gene. & Verplaetse et al., 2015 \\
\hline $\begin{array}{l}\text { Bt (pPabrB'gfp }{ }_{B t e} \mathrm{AAV}- \\
\text { PnprA'mcherry } \\
\text { LGC })\end{array}$ & $\begin{array}{l}\text { Bt } 407^{-} \text {in which we measure the activity of the promoter of abrB, using a reporter gene encoding an } \\
\text { unstable GFP, as well as the activity of the promoter of } n p r A \text {, using mcherry. }\end{array}$ & This study \\
\hline Bt (pPaphA3'sf $g f p)$ & $\begin{array}{l}\text { Bt } 407^{-} \text {used to measure the fluorescence generated by the transcriptional fusion between the } \\
\text { promoter of aphA3 and }{ }_{s f} g f p \text {. }\end{array}$ & This study \\
\hline
\end{tabular}


flow cytometry, we showed that the $g f p_{B t e}$-expressing cells grown in HCT medium were about 20 times brighter than the $s f g f p$ expressing cells, $2 \mathrm{~h}$ after the addition of xylose (Figure 1A; median fluorescence of 34 and 1.6 AU and pink and orange lines, respectively). Codon adaptation resulted in the most efficient improvement compared to the RBS modification and the com $G A$ sequence addition. Indeed, the $g f p_{B t}$-expressing cells are fivefold brighter than the ${ }_{s f} g f p$-expressing cells, whereas each subsequent modification step increased the fluorescence of the cells by approximately twofold (Figure 1A; median fluorescence of 8, 1.6, 22, and $34 \mathrm{AU}$ and blue, orange, green and pink lines, respectively). This increase in fluorescence intensity is visible on the microscopy pictures taken $2 \mathrm{~h}$ after xylose addition (Figures 1B-F).

\section{Construction of Unstable GFP Bte $_{\text {Variants }}$}

To monitor variations in gene expression, we decided to generate an unstable version of the $\mathrm{GFP}_{\text {Bte }}$. We used a previously described method that takes advantage of the $s s r A$-mediated peptide tagging system (Andersen et al., 1998). The principle of the method is to tag a protein for specific degradation by a protease. We added 10 amino acids at the N-terminal end of $\mathrm{GFP}_{\mathrm{Bte}}$ with a variation in the last 3 amino acids of the sequence (GKQNNLSLAA/-LVA/-AAV/-ASV), generating $\mathrm{GFP}_{\text {Bte }} \mathrm{LAA}, \mathrm{GFP}_{\mathrm{Bte}} \mathrm{LVA}, \mathrm{GFP}_{\mathrm{Bte}} \mathrm{AAV}$, and GFP $\mathrm{Bte}_{\mathrm{ASV}} \mathrm{AS}$. Amino acids GKQNNLSLAA correspond to the putative proteolytic tag added by the $s s r A$ tmRNA we identified in the genome of strain $B$. thuringiensis 407. These amino acids have been shown to address the tagged protein to the Clp degradation machinery in E. coli and in B. subtilis (Keiler et al., 1996; Gottesman et al., 1998; Wiegert and Schumann, 2001). Each tag variant should alter the stability of the protein (Keiler and Sauer, 1996; Andersen et al., 1998). We monitored the fluorescence of the cells harboring the $\mathrm{GFP}_{\mathrm{Bte}}$ tagged variants during growth in HCT medium and the results are presented on Figure 2. At the time of inducer addition, all the cells present a fluorescence similar to that of the reporterless cells (Figure 2A, left panel). $30 \mathrm{~min}$ after xylose induction, there is a striking difference between the cells harboring the wild-type -LAA or the -LVA tag and the cells harboring the -AAV or the -ASV tag (Figure 2A, second panel from the left). The latter present a fluorescence closer to that of the cells producing $\mathrm{GFP}_{\mathrm{Bte}}$ whereas the fluorescence of the former is weaker. $1 \mathrm{~h}$ after xylose induction (Figure 2A, third panel from the left), the cells harboring the $\mathrm{GFP}_{\mathrm{Bte}} \mathrm{LAA}$ or the $\mathrm{GFP}_{\mathrm{Bte}} \mathrm{LVA}$ tag had a similar fluorescence (median fluorescence of 2 and 2.3 AU which is 33- and 28-fold lower than that of GfpBte-producing cells, respectively). The cells expressing $g f p_{B t e}$ ASV were the most fluorescent (median fluorescence of 43AU, 1.5-fold lower than that of $g f p_{B t e}$-expressing cells), however, the histogram profile was not satisfying since it showed two peaks which indicate that $g f p$ expression and/or GFP degradation in the population was highly heterogeneous. The cells harboring the GFP $\mathrm{Bte}_{\mathrm{AAV}} \mathrm{AAresented} \mathrm{a}$ median fluorescence of $19 \mathrm{AU}$ that was 3.5-fold lower than that of the $\mathrm{GFP}_{\mathrm{Bte}}$-producing cells (median fluorescence of $65 \mathrm{AU}$ ) and a histogram profile similar to that of the latter. Two hours after addition of the inducer (Figure 2A, right panel), all the histograms were similar to those observed $1 \mathrm{~h}$ after induction.
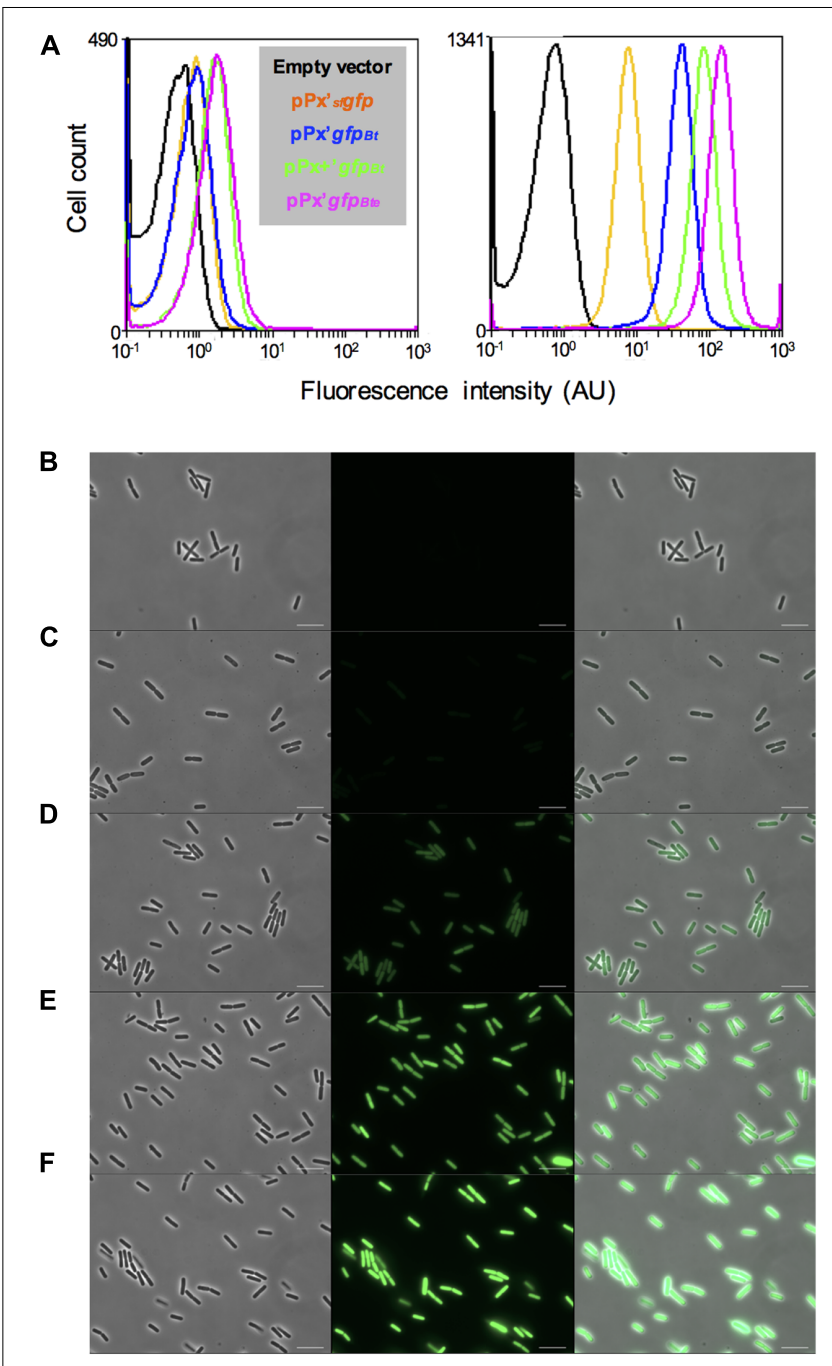

FIGURE 1 | Comparison of the GFP-based fluorescence of Bacillus thuringiensis strains. (A) Flow cytometry analysis of the $B$. thuringiensis cells harboring the empty vector p304-Pxyl+ (black), pPx'sf $g f p$ (orange), pPx'gfp $p_{B t}$ (blue), $\mathrm{pPx}+\mathrm{ffp}_{\mathrm{Bt}}$ (green) or $\mathrm{pPx}$ 'gfp $\mathrm{B}_{B \mathrm{te}}$ (pink). The left and right panels represent the fluorescence of the cells harvested when xylose was added and $2 \mathrm{~h}$ after xylose addition, respectively. The $X$-axis of the histograms is the fluorescence intensity in arbitrary units $(A U)$ in logarithmic scale. The $Y$-axis represents the cell count. (B-F) Fluorescence microscopy images of cells harboring p304-Pxyl+ (B), pPx'sf $g f p$ (C), pPx'gfp p $_{B t}$ (D), pPx+'gfp $p_{B t}$ (E), or

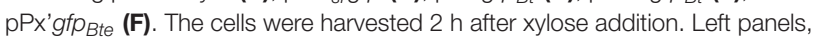
phase contrast images; middle panels, epifluorescence images; right panels, merge between the two channels. The scale bars represent $10 \mu \mathrm{m}$. These results are representative of two independent experiments.

$g f p_{\text {Bte-expressing cells were more fluorescent than } 1 \mathrm{~h} \text { before }}$ (median fluorescence of $125 \mathrm{AU}$ vs. $65 \mathrm{AU}$, respectively) whereas the fluorescence of $g f p_{B t e} \mathrm{AAV}$-expressing cells was similar at both times (median fluorescence of 19 AU and 15 AU 1 and $2 \mathrm{~h}$ after addition of xylose, respectively). $g f p_{B t e} \mathrm{AAV}$ was thus chosen as a reporter of gene expression for the subsequent experiments.

The decrease in fluorescence of $\mathrm{GFP}_{\mathrm{Bte}} \mathrm{AAV}$-producing cells was then monitored after the addition of chloramphenicol, an inhibitor of translation (Periago et al., 2002), to determine 

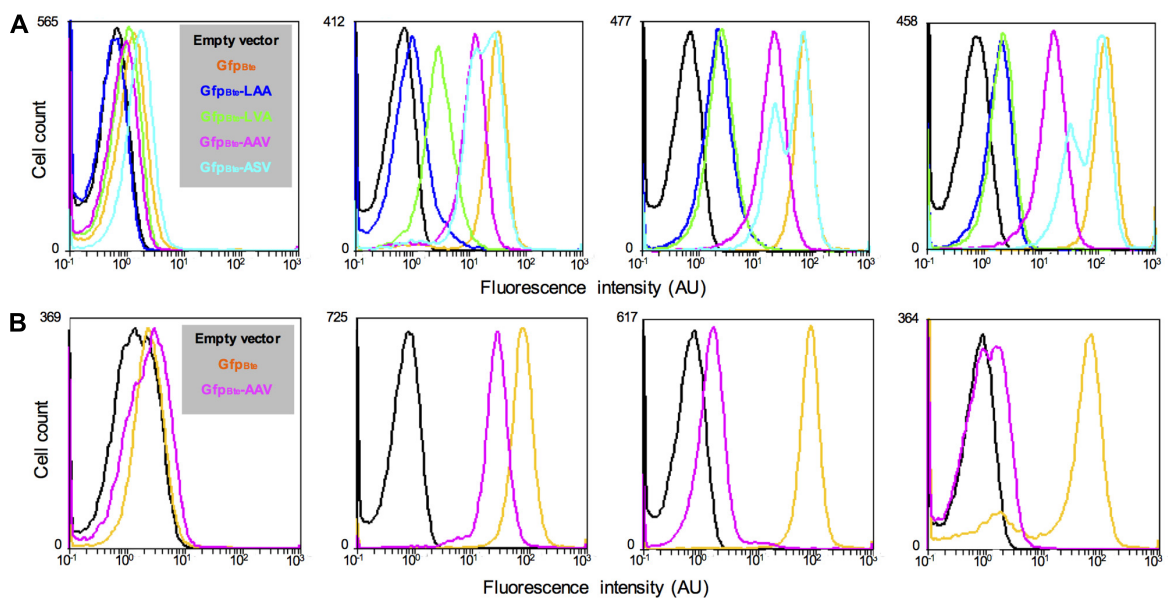

FIGURE 2 | Comparison of the fluorescence of $B$. thuringiensis strains harboring different alleles of $g f p_{B t e}$. (A) Flow cytometry analysis of the $B$. thuringiensis cells

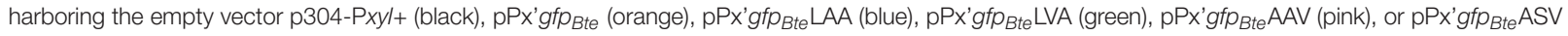
(turquoise). The cells were harvested when xylose was added, $30 \mathrm{~min}, 1 \mathrm{~h}$ and $2 \mathrm{~h}$ after xylose addition (panels from left to right). (B) Flow cytometry analysis of the B. thuringiensis cells harboring the empty vector p304-Pxyl+ (black), pPx'gfp ${ }_{B t e}$ (orange), and pPx'gfp Bte $^{A A V}$ (pink). From left to right, the histograms show the fluorescence of cells harvested when xylose was added, $1 \mathrm{~h}$ after xylose addition (which also corresponds to the time when chloramphenicol was added), 1 and $22 \mathrm{~h}$ after chloramphenicol addition. The $X$-axis of the histograms is the fluorescence intensity in arbitrary units (AU) in logarithmic scale. The $Y$-axis represents the cell count. These results are representative of two independent experiments.

GFP stability (Figure 2B). The median fluorescence of $g f p_{B t e^{-}}$ expressing cells was similar at the time of and $1 \mathrm{~h}$ after chloramphenicol addition (median fluorescence of $73 \mathrm{AU}$ and 77 AU, respectively) (Figure 2B, second and third panels from the left, respectively). In contrast, the median fluorescence of $g f p_{\text {Bte }} \mathrm{AAV}$-expressing cells decreased by 17 -fold between these two time-points (median fluorescence of $26 \mathrm{AU}$ and $1.5 \mathrm{AU}$, respectively). $22 \mathrm{~h}$ after chloramphenicol addition, the majority of the $g f p_{B t e}$-expressing cells remained fluorescent whereas the $g f p_{B t e} \mathrm{AAV}$-expressing cells presented a fluorescence close to that of the control cells (Figure 2B, right panel). These results indicate that, in these conditions, the $\mathrm{GFP}_{\mathrm{Bte}} \mathrm{AAV}$-based fluorescence shows a half-life of approximately $15 \mathrm{~min}$.

\section{Monitoring the Expression of $a b r B$ in Vitro Using gfp Bte $_{\text {AAV }}$}

In order to monitor the vegetative state of $B$. thuringiensis cells during the infectious cycle we chose to use the promoter of the $a b r B$ gene. This gene encodes a transition state regulator transcribed and active during the exponential phase (Perego et al., 1988; O’Reilly and Devine, 1997; Banse et al., 2008; Lucking et al., 2009). We monitored the fluorescence of the cells harboring a PabrB' $g f p_{B t e} \mathrm{AAV}$ transcriptional fusion during growth in LB medium and the results are presented on Figure 3. The data are from two independent experiments. We represented 2 negative control samples on the graph to account for the difference between the auto-fluorescence of the reporter-less cells at $\mathrm{t}-2$ and the cells harvested at the other time-points (Figure 3A, left panel). All the negative control histograms are shown in Supplementary Figure S1. The flow cytometry histograms show that the PabrB' $g f p_{B t e} \mathrm{AAV}$-expressing cells at $\mathrm{t}-2$ are already fluorescent compared to the negative control (median fluorescence of 2.1 vs. 0.4 AU, respectively) and their fluorescence increases until it reaches a maximum at $\mathrm{t}-1$ and $\mathrm{t} 0$ before decreasing at $\mathrm{t} 1$ and $\mathrm{t} 2$ (median fluorescence of 5.2, 5.8, 3.1, and 2.7 AU, respectively, to be compared to the light gray negative control with a median fluorescence of $0.8 \mathrm{AU}$ ) (Figure $\mathbf{3 A}$, left panel). At $\mathrm{t} 24$, the cells harboring PabrB'gfp $f_{\text {Bte }} \mathrm{AAV}$ do not present any fluorescence (Supplementary Figure S2). The shape of the histograms suggests that the PabrB'gfp $\mathrm{Bte}$ AAV fusion is expressed in a homogeneous fashion in the population (only 1 peak is visible). The right panel of Figure $\mathbf{3 A}$ recapitulates the data for both experiments as kinetics of median fluorescence intensity and shows that the peak of $\mathrm{P} a b r B^{\prime} g f p_{B t e} \mathrm{AAV}$ expression was reached between $\mathrm{t}-1$ and $\mathrm{t} 0$. Microscopy pictures of $\mathrm{PabrB}$ 'gfp $\mathrm{p}_{\text {Bte }} \mathrm{AAV}$-expressing cells harvested at $\mathrm{t} 0$ and at $\mathrm{t} 2$ support the flow cytometry data (Figure 3B). These results show that the PabrB'gfp $p_{B t e} \mathrm{AAV}$ transcriptional fusion is expressed during exponential phase and that we can visualize a decrease in its expression when the cells enter the transition phase.

\section{abrB Expression Is Activated in Cells That Have Entered the Necrotrophic Pathway}

We investigated the physiological state of $B$. thuringiensis cells during infection in order to characterize in more detail the composition of the population during this cycle. To achieve this objective we examined the state of the cells that did not activate the promoters previously used, in particular the necrotrophic reporter (Verplaetse et al., 2015). We infected $G$. mellonella larvae with $B$. thuringiensis cells harboring the PnprA'mcherry ${ }_{\mathrm{LGC}}$ transcriptional fusion as well as the PabrB' $g f p_{B t e}$ AAV transcriptional fusion on the same vector. $n p r A$ is under the control of $\mathrm{NprR}$, the regulator of the necrotrophic 


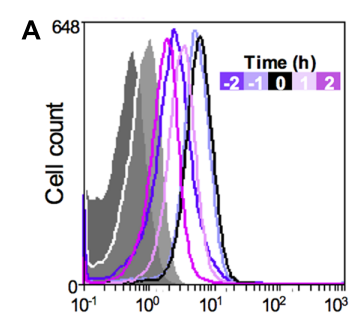

Fluorescence intensity (AU)

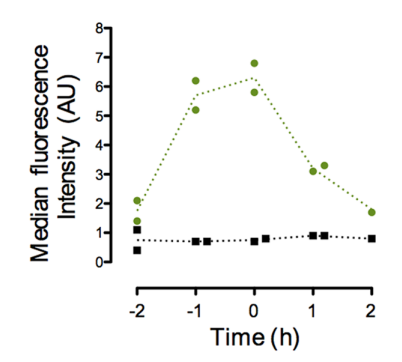

B

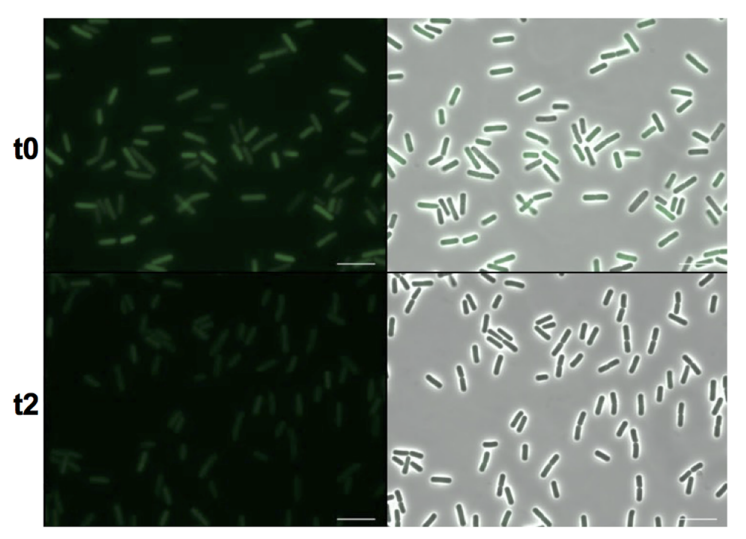

FIGURE 3 | Expression of the abrB-driven gfp ${ }_{B t e} A A V$ gene in vitro. (A) Left panel: flow cytometry analysis of the $B$. thuringiensis cells harboring the empty vector pHT304 (gray areas) or pPabrB'gfp ${ }_{B t e}$ AAV (lines). The cells were grown in LB and harvested at various times during growth that can be identified with the time map on the graph. The negative control cells represented here were harvested at t-2 (dark gray) and t2 (light gray). The $X$-axis of the histograms is the fluorescence intensity in arbitrary units (A.U.) in logarithmic scale. The $Y$-axis represents the cell count. These results are representative of two independent experiments. Right panel: median fluorescence intensity of the same cells represented as a function of time. Black squares, $B$. thuringiensis cells harboring the empty vector pHT304; Green dots, $B$. thuringiensis cells harboring pPabrB'gfp ${ }_{B t e} A A V$. Each dot/square represents a replicate. The dotted lines connect the mean values at each time point. (B) Fluorescence microscopy images of cells harboring pPabrB'gfp ${ }_{B t e} A A V$ at t0 and t2. Left panels, epifluorescence images; right panels, merge between the two channels. The scale bar represents $10 \mu \mathrm{m}$. t0 corresponds to the beginning of the transition between the exponential and stationary phases. These results are representative of two independent experiments.

state, and reflects its activity (Perchat et al., 2011). We monitored the fluorescence of the cells harvested from the insect cadavers at various times following infection. The results are presented in Figure 4. The kinetics profile of the $\mathrm{Nec}+$ population (i.e., cells expressing $n p r A$ ) is similar to what has been published before (Verplaetse et al., 2015) with a low percentage of the population expressing nprA $18 \mathrm{~h}$ post-infection (pi) (mean value of 11\%) that increases between 24 and $48 \mathrm{~h}$ pi (mean values of 27 and $68 \%$, respectively) to reach a maximum $72 \mathrm{~h}$ pi (mean value of $74 \%$ ). We observed that the vegetative PabrB' $g f p_{B t e} \mathrm{AAV}$ reporter is expressed at $18 \mathrm{~h}$ pi in $13 \%$ of the population. Interestingly, less cells expressed it at $24 \mathrm{~h}$ pi (mean value of $4 \%$ ). The percentage of cells in which $\mathrm{PabrB}$ is expressed increased at 48 and $72 \mathrm{~h}$ pi (mean value of 15 and $22 \%$, respectively). The expression of $\mathrm{PabrB}$ ' $g f p_{B t e} \mathrm{AAV}$ is almost exclusively restricted

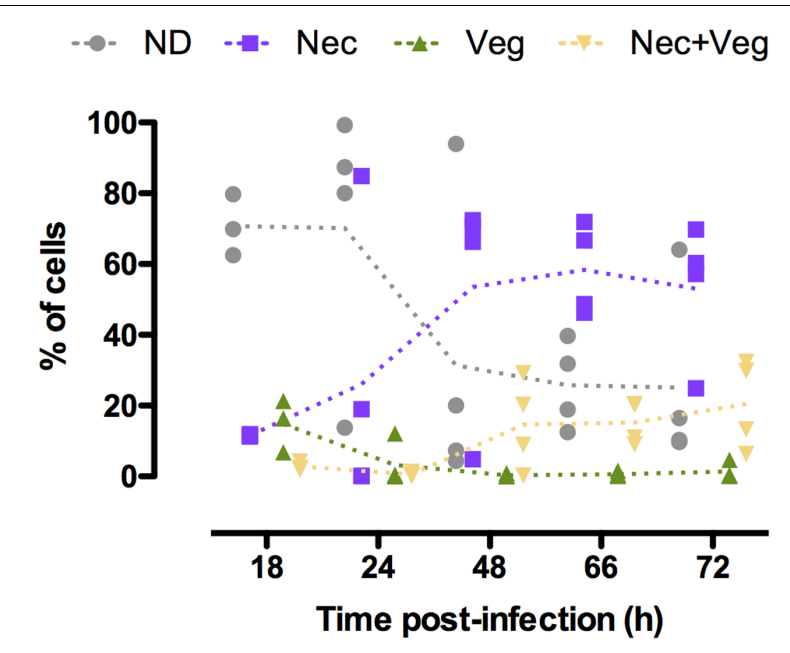

FIGURE $4 \mid a b r B$ and nprA promoter activities in cells isolated from insect cadavers. Flow cytometry analysis of $B$. thuringiensis cells harboring pPabrB'gfp ${ }_{B t e} A A V-P n p r A ' m c h e r r y ~ L G C$. Bacteria were isolated from cadavers of $G$. mellonella larvae infected by intrahemocoelic injection and incubated at $30^{\circ} \mathrm{C}$. Samples were harvested $18,24,48,66$, and $72 \mathrm{~h}$ after injection. The percentage of cells of each population discriminated on cytograms (as described in the Supplementary Experimental Procedures) are presented as a function of time. Each population phenotype is associated to a color as indicated on the graph: ND, cells that do not express any of the markers used; Nec, cells expressing the necrotrophic marker PnprA'mcherry ${ }_{L G C}$ only; Veg, cells expressing the vegetative growth marker PabrB'gfp ${ }_{B t e} A A V$ only; $\mathrm{Nec}+\mathrm{Veg}$, cells expressing both the vegetative growth and necrotrophic markers. Each symbol represents bacteria extracted from one larva. The dotted lines connect the mean values at each time point. These data are the result of two independent experiments.

to cells that have activated the nprA gene promoter from 48 to $72 \mathrm{~h}$ pi. Figure 4 also shows that the proportion of cells that did not express the necrotrophic or the vegetative reporters changed from $71 \%$ at $18 \mathrm{~h}$ pi to $25 \% 72 \mathrm{~h}$ pi. In order to verify that the expression patterns observed were not due to loss or copy number heterogeneity of the plasmid during the infectious process, we infected G. mellonella larvae with $B$. thuringiensis cells harboring the $\mathrm{pPaphA3}{ }^{\prime} f f f p$ vector carrying a transcriptional fusion between the promoter of a constitutive gene in $B$. thuringiensis, and the reporter gene encoding ${ }_{\text {sf }}$ GFP. The results show that the fusion is expressed in a homogeneous fashion in the population 24 and $72 \mathrm{~h}$ pi (only 1 peak is visible) (Supplementary Figure S3). Furthermore, a previous study has reported that 100 and $99.3 \%$ of the bacteria harvested from insect cadavers still carried a vector with the same backbone 48 and $96 \mathrm{~h}$ post-infection, respectively (Verplaetse et al., 2015). This indicates that the phenotypic heterogeneity observed for the reporters mentioned above is not due to plasmid instability or copy number heterogeneity in $B$. thuringiensis during infection.

\section{Cells That Did Not Enter the Necrotrophic Pathway Are Viable}

In order to verify that the bacteria that did not express any of the reporters used were alive, we infected $G$. mellonella larvae with $B$. thuringiensis cells harboring the PnprA'mcherry $y_{L C}$ 


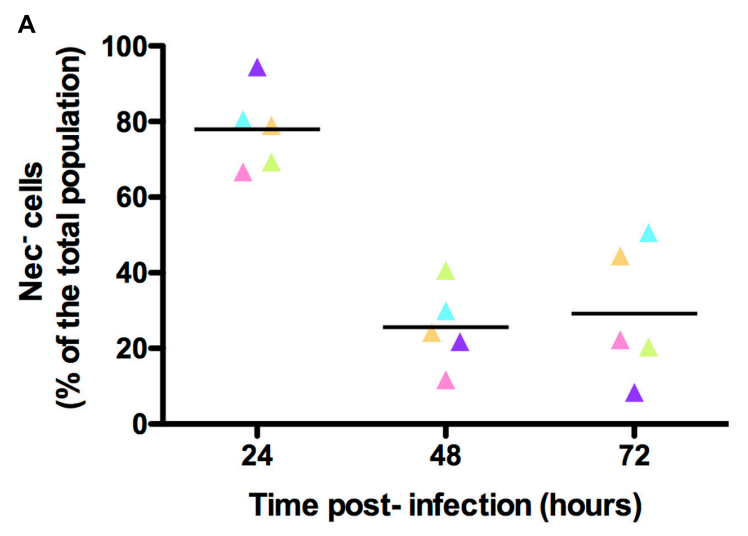

B

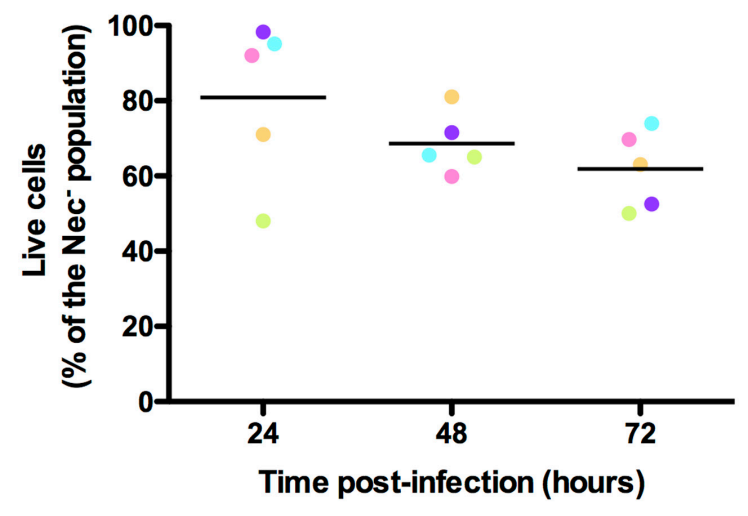

FIGURE 5 | Viability assessment of the bacterial cells isolated from insect cadavers. Flow cytometry analysis of $B$. thuringiensis cells harboring pPnprA'mcherry ${ }_{L G C}$ and stained with the SYTOX Green Dead Cell Stain. Bacteria were isolated from cadavers of $G$. mellonella larvae infected by intrahemocoelic injection and incubated at $30^{\circ} \mathrm{C}$. Samples were harvested 24 , 48 , and $72 \mathrm{~h}$ after injection. The percentage of cells of each population discriminated on cytograms (as described in the Supplementary Experimental Procedures) are presented as a function of time. (A) Percentage of cells that did not enter the necrotrophic pathway $\left(\mathrm{Nec}^{-}\right)$. (B) Percentage of cells that did not enter the necrotrophic pathway and that were considered live using the SYTOX Green Dead Cell Stain. Each symbol represents bacteria extracted from one larva. The color of the symbols for each time point in $(\mathbf{A}, \mathbf{B})$ indicates bacteria extracted from the same larva. These data are the result of two independent experiments and the lines represent the mean values at each time point.

transcriptional fusion and incubated the samples harvested from the insect cadavers at various times following infection with the SYTOX Green Dead Cell Stain. We then immediately monitored the mCherry- and SYTOX Green-based fluorescence of the bacteria. The cells recovered at each time-point were mostly alive. Indeed 89,79 , and $84 \%$ of the bacteria were not stained by the SYTOX Green Dead Cell dye at 24, 48, and $72 \mathrm{~h}$ pi, respectively (Supplementary Figure S4). Figure 5A shows that in

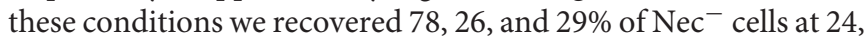
48 , and $72 \mathrm{~h}$ pi, respectively. In these samples, the SYTOX Green stain shows that 81,69 , and $62 \%$ of the $\mathrm{Nec}^{-}$bacteria were live cells, respectively (Figure 5B). This indicates that the majority of the cells that did not express any of the reporters used were not dead.

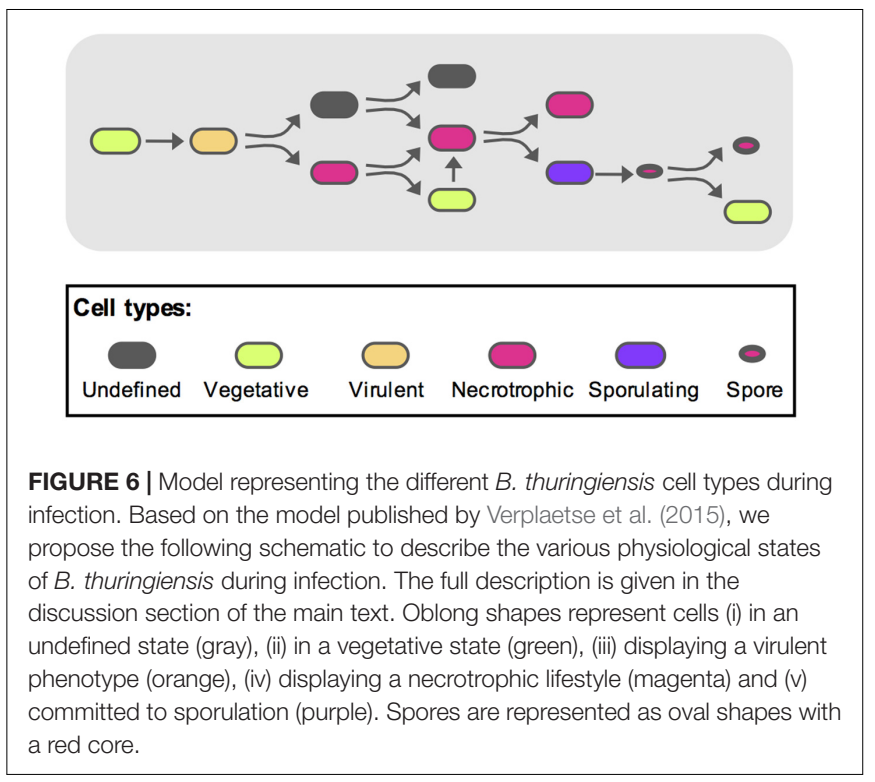

\section{DISCUSSION}

Our initial goal was to characterize in more detail the composition of the $B$. thuringiensis population during the infectious process. We were interested in particular by the cells that did not express any of the reporters we used in a previous study, especially the necrotrophic state reporter (Verplaetse et al., 2015).

To begin to answer this question we constructed a genetic tool to enable us to follow gene expression fluctuations using a fluorescent reporter. We used the $s s r A$-mediated peptide tagging system (for a review Karzai et al., 2000) that was published for the first time by Andersen et al. (1998) as a tool to destabilize GFP in order to follow transient gene expression in bacteria. Destabilizing the GFP would reduce the fluorescence of the cells harboring this construct. Thus, it was also necessary to improve its fluorescence in B. thuringiensis cells. GFP improvement has been described for other bacterial species (Veening et al., 2004; Overkamp et al., 2013) and even bacteria of the B. cereus group (using gfpmut1 as the original template) (Sastalla et al., 2009). We designed a new construct $-g f p_{B t e}$ - based on the sf $g f p$ allele mainly because of its fast-folding properties (Pedelacq et al., 2006; Milde, 2008). The $B$. thuringiensis cells expressing $g f_{p_{B t e}}$ were 20 -fold brighter than the ones harboring the initial construct. The best improvement resulted from the codon optimization. Destabilization of the protein was then accomplished by adding a degradation tag to the $\mathrm{GFP}_{\text {Bte }}$. The resulting $\mathrm{GFP}_{\mathrm{Bte}} \mathrm{AAV}$ rendered the cells almost as fluorescent as the ones without the tag, but with a half-life of approximately 15 min compared to at least $7.5 \mathrm{~h}$ for the original construct. This destabilization method has been adapted by various laboratories to different bacterial species (for example Blokpoel et al., 2003; Hentschel et al., 2013; Mouammine et al., 2017). However, to our knowledge, this system has been only used in very few and elegant studies to monitor fluctuations in gene activity in an infection model (Nielsen et al., 2010; Laughlin et al., 2014). 
We fused the $g f p_{B t e} \mathrm{AAV}$ reporter gene to the promoter of $a b r B$ and associated it to the PnprA'mcherry ${ }_{L G C}$ transcriptional fusion to determine if the bacteria that did not go through the necrotrophic state during the course of infection were vegetative cells. We saw that the promoter of the $a b r B$ gene was active throughout the infection cycle, at least from $18 \mathrm{~h}$ pi to $72 \mathrm{~h}$ pi. At $18 \mathrm{~h}$ pi a large number of bacteria did not express either reporter. We cannot exclude that these cells expressed the PabrB'gfp $p_{\text {Bte }} \mathrm{AAV}$ fusion during the early stage of the infection, considering the unstable nature of the fluorescent protein and the fact that at this time point, the bacteria have reached a growth plateau after a period of active multiplication (Dubois et al., 2016). The proportion of vegetative cells and of undetermined cells then diminished as the proportion of necrotrophic cells increased. This was expected as the necrotrophic marker is a stationary phase marker. However, we did not expect the cells that went through the necrotrophic state to activate the PabrB promoter. The stability of the mCherry protein [half-life of more than $50 \mathrm{~h}$ (Verplaetse et al., 2015)] is a double-edged property. It allows us to follow the cells that went through the necrotrophic state but we do not know when -or if- they stopped expressing the necrotrophism genes. Using a fluorescent protein whose spectral properties change with time could help solve this issue (Terskikh et al., 2000). We hypothesize that the cells that activated $\mathrm{PabrB}$ were no longer in a necrotrophic state and that they resumed vegetative growth following a signal that they sensed. It was shown that the sporulating cells arose almost exclusively from necrotrophic cells in the host cadaver (Verplaetse et al., 2015). It is possible that reactivation of the vegetative state is a way of delaying sporulation in some cells. Sporulation is a costly and, at some point, irreversible process (Piggot and Hilbert, 2004). In B. subtilis, bacteria that have engaged in sporulation use toxins to kill non-sporulating cells (for a review Gonzalez-Pastor, 2011). This allows the non-committed sporulating cells to arrest sporulation and resume growth by using nutrients provided by the lysis of neighboring cells. Sporulation delay might be why the cells reenter a vegetative state in this PabrB'gfp $p_{B t e} A A V$-expressing subpopulation. The mechanism by which this could occur remains to be elucidated. Another hypothesis, which would not exclude the above mentioned one, would be that some of the spores germinated. Indeed, the spores, that originate from necrotrophic cells, retain an mCherry-based fluorescence (Verplaetse et al., 2015 , 2016) and the PabrB promoter is activated while spores are in the process of germination (data not shown). It is likely that if nutrients become accessible, at least some of the spores will germinate.

To recapitulate these events and integrate them with the previously published data (Verplaetse et al., 2015), we propose the following model as schematized on Figure 6. During the early steps of infection, the bacteria activate the vegetative state marker while multiplying. After the virulence stage and death of the host, the bacterial number has reached a plateau and part of the population will turn on the necrotrophic genes. Among these bacteria, some will re-enter a vegetative state. These cells will subsequently have to activate the necrotrophic genes before sporulation can occur in part of this sub-population. Some spores are then able to germinate and resume vegetative growth. During this infectious cycle, some bacteria do not fit in any of the categories mentioned above. Indeed, the cells that did not go through the necrotrophic state did not appear to activate the PabrB promoter. About $20 \%$ of the population are still in an undetermined state. However, we have shown that about $70 \%$ of these bacteria are viable. This suggests that these cells could be dormant. Dormancy has been studied in Gram-positive and Gram-negative bacteria as a successful survival strategy (Rittershaus et al., 2013; Verstraeten et al., 2016). However, these species were non-sporulating. In sporulating bacteria, the spore is the ultimate form of dormancy. Nevertheless, a quiescent physiological state would constitute an alternative to the complex process of sporulation. Indeed, once the cells are committed to sporulation, they would not be able to return quickly to a vegetative state if competing bacteria invaded their niche. And bacteria in such a quiescent state could rapidly return to exponential growth, compared to germination, if favorable conditions were encountered, or might respond to a different resuscitation signal than that of germination. Many questions remain to be answered, such as the ability of these cells to grow back from this state. Their infectious capacity as well as their gene expression profiles during infection should also be investigated to determine if they can reproduce the parental phenotypes. We are now in the process of pursuing this research further.

\section{AUTHOR CONTRIBUTIONS}

Conceived and designed the study: LS and DL. Designed the experiments: LS. Performed the experiments: SBR and LS. Analyzed the data: LS, SBR, and DL. Wrote the paper: LS.

\section{FUNDING}

The CyFlow space flow cytometer used in this study was funded by the DIM Astrea (French regional program: Ast11 0137). This work was supported by the INRA (the National Institute for Agronomical Research). SBR was financed by an INRA apprenticeship grant.

\section{ACKNOWLEDGMENTS}

The authors thank Morgane Girault for her help with the experiments related to the $g f p$ modifications. They are grateful to Christophe Buisson, Agnès Réjasse, and Christina NielsenLeRoux for their involvement in the in vivo experiments and to Emilie Verplaetse for helpful discussions.

\section{SUPPLEMENTARY MATERIAL}

The Supplementary Material for this article can be found online at: https://www.frontiersin.org/articles/10.3389/fmicb. 2017.02471/full\#supplementary-material 


\section{REFERENCES}

Agaisse, H., and Lereclus, D. (1994). Structural and functional analysis of the promoter region involved in full expression of the cryIIIA toxin gene of Bacillus thuringiensis. Mol. Microbiol. 13, 97-107. doi: 10.1111/j.1365-2958. 1994.tb00405.x

Andersen, J. B., Sternberg, C., Poulsen, L. K., Bjorn, S. P., Givskov, M., and Molin, S. (1998). New unstable variants of green fluorescent protein for studies of transient gene expression in bacteria. Appl. Environ. Microbiol. 64, 2240-2246.

Arantes, O., and Lereclus, D. (1991). Construction of cloning vectors for Bacillus thuringiensis. Gene 108, 115-119. doi: 10.1016/0378-1119(91)90495-W

Banse, A. V., Chastanet, A., Rahn-Lee, L., Hobbs, E. C., and Losick, R. (2008). Parallel pathways of repression and antirepression governing the transition to stationary phase in Bacillus subtilis. Proc. Natl. Acad. Sci. U.S.A. 105, 15547-15552. doi: 10.1073/pnas.0805203105

Blokpoel, M. C., O'toole, R., Smeulders, M. J., and Williams, H. D. (2003). Development and application of unstable GFP variants to kinetic studies of mycobacterial gene expression. J. Microbiol. Methods 54, 203-211. doi: 10.1016/ S0167-7012(03)00044-7

Bottone, E. J. (2010). Bacillus cereus, a volatile human pathogen. Clin. Microbiol. Rev. 23, 382-398. doi: 10.1128/CMR.00073-09

Deng, C., Peng, Q., Song, F., and Lereclus, D. (2014). Regulation of cry gene expression in Bacillus thuringiensis. Toxins 6, 2194-2209. doi: 10.3390/ toxins 6072194

Dubois, T., Faegri, K., Gelis-Jeanvoine, S., Perchat, S., Lemy, C., Buisson, C., et al. (2016). Correction: necrotrophism is a quorum-sensing-regulated lifestyle in Bacillus thuringiensis. PLOS Pathog. 12:e1006049. doi: 10.1371/journal.ppat. 1006049

Fedhila, S., Daou, N., Lereclus, D., and Nielsen-Leroux, C. (2006). Identification of Bacillus cereus internalin and other candidate virulence genes specifically induced during oral infection in insects. Mol. Microbiol. 62, 339-355. doi: 10.1111/j.1365-2958.2006.05362.x

Gonzalez-Pastor, J. E. (2011). Cannibalism: a social behavior in sporulating Bacillus subtilis. FEMS Microbiol. Rev. 35, 415-424. doi: 10.1111/j.1574-6976.2010. 00253.x

Gottesman, S., Roche, E., Zhou, Y., and Sauer, R. T. (1998). The ClpXP and ClpAP proteases degrade proteins with carboxy-terminal peptide tails added by the SsrA-tagging system. Genes Dev. 12, 1338-1347. doi: 10.1101/gad.12.9.1338

Grandvalet, C., Gominet, M., and Lereclus, D. (2001). Identification of genes involved in the activation of the Bacillus thuringiensis inhA metalloprotease gene at the onset of sporulation. Microbiology 147, 1805-1813. doi: 10.1099/ 00221287-147-7-1805

Guerout-Fleury, A. M., Shazand, K., Frandsen, N., and Stragier, P. (1995). Antibiotic-resistance cassettes for Bacillus subtilis. Gene 167, 335-336. doi: 10.1016/0378-1119(95)00652-4

Hentschel, E., Will, C., Mustafi, N., Burkovski, A., Rehm, N., and Frunzke, J. (2013). Destabilized eYFP variants for dynamic gene expression studies in Corynebacterium glutamicum. Microb. Biotechnol. 6, 196-201. doi: 10.1111/j. 1751-7915.2012.00360.x

Karzai, A. W., Roche, E. D., and Sauer, R. T. (2000). The SsrA-SmpB system for protein tagging, directed degradation and ribosome rescue. Nat. Struct. Biol. 7, 449-455. doi: 10.1038/75843

Keiler, K. C., and Sauer, R. T. (1996). Sequence determinants of C-terminal substrate recognition by the Tsp protease. J. Biol. Chem. 271, 2589-2593. doi: 10.1074/jbc.271.5.2589

Keiler, K. C., Waller, P. R., and Sauer, R. T. (1996). Role of a peptide tagging system in degradation of proteins synthesized from damaged messenger RNA. Science 271, 990-993. doi: 10.1126/science.271.5251.990

Laughlin, R. C., Knodler, L. A., Barhoumi, R., Payne, H. R., Wu, J., Gomez, G., et al. (2014). Spatial segregation of virulence gene expression during acute enteric infection with Salmonella enterica serovar Typhimurium. MBio 5, e00946-13. doi: 10.1128/mBio.00946-13

Lereclus, D., Arantes, O., Chaufaux, J., and Lecadet, M. (1989). Transformation and expression of a cloned delta-endotoxin gene in Bacillus thuringiensis. FEMS Microbiol. Lett. 51, 211-217.

Lereclus, D., Lecadet, M. M., Ribier, J., and Dedonder, R. (1982). Molecular relationships among plasmids of Bacillus thuringiensis: conserved sequences through 11 crystalliferous strains. Mol. Gen. Genet. 186, 391-398. doi: 10.1007/ BF00729459

Lopez, D., and Kolter, R. (2010). Extracellular signals that define distinct and coexisting cell fates in Bacillus subtilis. FEMS Microbiol. Rev. 34, 134-149. doi: 10.1111/j.1574-6976.2009.00199.x

Lucking, G., Dommel, M. K., Scherer, S., Fouet, A., and Ehling-Schulz, M. (2009). Cereulide synthesis in emetic Bacillus cereus is controlled by the transition state regulator AbrB, but not by the virulence regulator PlcR. Microbiology 155, 922-931. doi: 10.1099/mic.0.024125-0

MacNeil, D. J., Gewain, K. M., Ruby, C. L., Dezeny, G., Gibbons, P. H., and Macneil, T. (1992). Analysis of Streptomyces avermitilis genes required for avermectin biosynthesis utilizing a novel integration vector. Gene 111, 61-68. doi: 10.1016/0378-1119(92)90603-M

Milde, S. (2008). Improved Fluorescent Proteins for Synthetic Biology. Available at: http://www.openwetware.org/wiki/IGEM:Cambridge/2008/Improved_GFP

Mock, M., and Fouet, A. (2001). Anthrax. Annu. Rev. Microbiol. 55, 647-671. doi: 10.1146/annurev.micro.55.1.647

Mouammine, A., Pages, S., Lanois, A., Gaudriault, S., Jubelin, G., Bonabaud, M., et al. (2017). An antimicrobial peptide-resistant minor subpopulation of Photorhabdus luminescens is responsible for virulence. Sci. Rep. 7:43670. doi: $10.1038 /$ srep 43670

Nielsen, A. T., Dolganov, N. A., Rasmussen, T., Otto, G., Miller, M. C., Felt, S. A., et al. (2010). A bistable switch and anatomical site control Vibrio cholerae virulence gene expression in the intestine. PLOS Pathog. 6:e1001102. doi: 10.1371/journal.ppat.1001102

O’Reilly, M., and Devine, K. M. (1997). Expression of AbrB, a transition state regulator from Bacillus subtilis, is growth phase dependent in a manner resembling that of Fis, the nucleoid binding protein from Escherichia coli. J. Bacteriol. 179, 522-529. doi: 10.1128/jb.179.2.522-529.1997

Overkamp, W., Beilharz, K., Detert Oude Weme, R., Solopova, A., Karsens, H., Kovacs, A., et al. (2013). Benchmarking various green fluorescent protein variants in Bacillus subtilis, Streptococcus pneumoniae, and Lactococcus lactis for live cell imaging. Appl. Environ. Microbiol. 79, 6481-6490. doi: 10.1128/AEM. 02033-13

Pedelacq, J. D., Cabantous, S., Tran, T., Terwilliger, T. C., and Waldo, G. S. (2006). Engineering and characterization of a superfolder green fluorescent protein. Nat. Biotechnol. 24, 79-88. doi: 10.1038/nbt1172

Perchat, S., Dubois, T., Zouhir, S., Gominet, M., Poncet, S., Lemy, C., et al. (2011). A cell-cell communication system regulates protease production during sporulation in bacteria of the Bacillus cereus group. Mol. Microbiol. 82, 619-633. doi: 10.1111/j.1365-2958.2011.07839.x

Perchat, S., Talagas, A., Poncet, S., Lazar, N., Li De La Sierra-Gallay, I., Gohar, M., et al. (2016). How quorum sensing connects sporulation to necrotrophism in Bacillus thuringiensis. PLOS Pathog. 12:e1005779. doi: 10.1371/journal.ppat. 1005779

Perego, M., Spiegelman, G. B., and Hoch, J. A. (1988). Structure of the gene for the transition state regulator, $a b r B$ : regulator synthesis is controlled by the spo0A sporulation gene in Bacillus subtilis. Mol. Microbiol. 2, 689-699. doi: 10.1111/j.1365-2958.1988.tb00079.x

Periago, P. M., Van Schaik, W., Abee, T., and Wouters, J. A. (2002). Identification of proteins involved in the heat stress response of Bacillus cereus ATCC 14579. Appl. Environ. Microbiol. 68, 3486-3495. doi: 10.1128/AEM.68.7.3486-3495. 2002

Piggot, P. J., and Hilbert, D. W. (2004). Sporulation of Bacillus subtilis. Curr. Opin. Microbiol. 7, 579-586. doi: 10.1016/j.mib.2004.10.001

Raymond, B., Johnston, P. R., Nielsen-Leroux, C., Lereclus, D., and Crickmore, N. (2010). Bacillus thuringiensis: an impotent pathogen? Trends Microbiol. 18, 189-194. doi: 10.1016/j.tim.2010.02.006

Rittershaus, E. S., Baek, S. H., and Sassetti, C. M. (2013). The normalcy of dormancy: common themes in microbial quiescence. Cell Host Microbe 13, 643-651. doi: 10.1016/j.chom.2013.05.012

Salamitou, S., Ramisse, F., Brehelin, M., Bourguet, D., Gilois, N., Gominet, M., et al. (2000). The PlcR regulon is involved in the opportunistic properties of Bacillus thuringiensis and Bacillus cereus in mice and insects. Microbiology 146( Pt 11), 2825-2832. doi: 10.1099/00221287-146-11-2825

Sanahuja, G., Banakar, R., Twyman, R. M., Capell, T., and Christou, P. (2011). Bacillus thuringiensis: a century of research, development and commercial 
applications. Plant Biotechnol. J. 9, 283-300. doi: 10.1111/j.1467-7652.2011. 00595.x

Sanchis, V. (2011). From microbial sprays to insect-resistant transgenic plants: history of the biopesticide Bacillus thuringiensis. A review. Agron. Sustain. Dev. 31, 217-231. doi: 10.1051/agro/2010027

Sastalla, I., Chim, K., Cheung, G. Y., Pomerantsev, A. P., and Leppla, S. H. (2009). Codon-optimized fluorescent proteins designed for expression in low-GC gram-positive bacteria. Appl. Environ. Microbiol. 75, 2099-2110. doi: 10.1128/AEM.02066-08

Slamti, L., Lemy, C., Henry, C., Guillot, A., Huillet, E., and Lereclus, D. (2015). CodY regulates the activity of the virulence quorum sensor PlcR by controlling the import of the signaling peptide PapR in Bacillus thuringiensis. Front. Microbiol. 6:1501. doi: 10.3389/fmicb.2015.01501

Slamti, L., and Lereclus, D. (2002). A cell-cell signaling peptide activates the $\mathrm{PlcR}$ virulence regulon in bacteria of the Bacillus cereus group. EMBO J. 21, 4550-4559. doi: 10.1093/emboj/cdf450

Slamti, L., Perchat, S., Huillet, E., and Lereclus, D. (2014). Quorum sensing in Bacillus thuringiensis is required for completion of a full infectious cycle in the insect. Toxins (Basel) 6, 2239-2255. doi: 10.3390/toxins608 2239

Stammen, S., Muller, B. K., Korneli, C., Biedendieck, R., Gamer, M., FrancoLara, E., et al. (2010). High-yield intra- and extracellular protein production using Bacillus megaterium. Appl. Environ. Microbiol. 76, 4037-4046. doi: 10.1128/AEM.00431-10

Stenfors Arnesen, L. P., Fagerlund, A., and Granum, P. E. (2008). From soil to gut: Bacillus cereus and its food poisoning toxins. FEMS Microbiol. Rev. 32, 579-606. doi: 10.1111/j.1574-6976.2008.00112.x

Strauch, M. A., and Hoch, J. A. (1993). Transition-state regulators: sentinels of Bacillus subtilis post-exponential gene expression. Mol. Microbiol. 7, 337-342. doi: 10.1111/j.1365-2958.1993.tb01125.x

Taylor, R. G., Walker, D. C., and Mcinnes, R. R. (1993). E. coli host strains significantly affect the quality of small scale plasmid DNA preparations used for sequencing. Nucleic Acids Res. 21, 1677-1678. doi: 10.1093/nar/21.7. 1677
Terskikh, A., Fradkov, A., Ermakova, G., Zaraisky, A., Tan, P., Kajava, A. V., et al. (2000). "Fluorescent timer": protein that changes color with time. Science 290, 1585-1588. doi: 10.1126/science.290.5496.1585

Veening, J. W., Smits, W. K., Hamoen, L. W., Jongbloed, J. D., and Kuipers, O. P. (2004). Visualization of differential gene expression by improved cyan fluorescent protein and yellow fluorescent protein production in Bacillus subtilis. Appl. Environ. Microbiol. 70, 6809-6815. doi: 10.1128/AEM.70.11. 6809-6815.2004

Verplaetse, E., Slamti, L., Gohar, M., and Lereclus, D. (2015). Cell differentiation in a Bacillus thuringiensis population during planktonic growth, biofilm formation, and host infection. MBio 6, e00138-e00115. doi: 10.1128/mBio. 00138-15

Verplaetse, E., Slamti, L., Gohar, M., and Lereclus, D. (2016). Two distinct pathways lead Bacillus thuringiensis to commit to sporulation in biofilm. Res. Microbiol. 168, 388-393. doi: 10.1016/j.resmic.2016.03.006

Verstraeten, N., Knapen, W., Fauvart, M., and Michiels, J. (2016). A historical perspective on bacterial persistence. Methods Mol. Biol. 1333, 3-13. doi: 10.1007/978-1-4939-2854-5_1

Vlamakis, H., Aguilar, C., Losick, R., and Kolter, R. (2008). Control of cell fate by the formation of an architecturally complex bacterial community. Genes Dev. 22, 945-953. doi: 10.1101/gad.1645008

Wiegert, T., and Schumann, W. (2001). SsrA-mediated tagging in Bacillus subtilis. J Bacteriol 183, 3885-3889. doi: 10.1128/JB.183.13.3885-3889.2001

Conflict of Interest Statement: The authors declare that the research was conducted in the absence of any commercial or financial relationships that could be construed as a potential conflict of interest.

Copyright (c) 2017 Ben Rejeb, Lereclus and Slamti. This is an open-access article distributed under the terms of the Creative Commons Attribution License (CC BY). The use, distribution or reproduction in other forums is permitted, provided the original author(s) or licensor are credited and that the original publication in this journal is cited, in accordance with accepted academic practice. No use, distribution or reproduction is permitted which does not comply with these terms. 